\title{
Challenges of Companies Operating in BoP Markets. Case of Albania
}

\author{
Manol Simo, Ph.D. Candidate \\ European University of Tirana, Faculty of Economy, \\ Department of Management and Economics
}

\section{Doi:10.5901/ajis.2013.v2n9p635}

\begin{abstract}
Near a decade ago, business academics C.K. Prahalad and Stuart Hart presented in their working paper a revolutionary concept of doing business in the world's poor markets known as the Bottom of Pyramid (BoP). These authors made the observation that about 4 billion people remain excluded from the system of the global economy. The world is experiencing a shift of power from the traditional industrialized countries to the so-called developing countries, already home to $80 \%$ of the world's population and with a combined GDP that surpasses that of the rich countries. The BoP concept encourages corporations to take into consideration this segment of the population, and consider this market as an opportunity to explore the untapped potential it presents. In this context, the BoP market represents a multibillion-dollar marketplace, which still remains unexploited from multinational or local companies. Maturing markets, floundering business models and insecurities about the characteristics of future customers, could be some of the reasons why corporations should pay attention to the BoP market. The market opportunity here is not just the wealthy few in the developing world, but the vast number of aspiring poor who are joining the market economy for the first time. The purpose of this paper is to review the existing literature on BoP and show some of the principles and techniques that Albanian companies might use in this segment of the market and how they cope with these principles.
\end{abstract}

Keywords: Business strategy, social business, partnership, inclusive business, innovation, poverty reduction

\section{Theoretical Background}

Near a decade ago, business academics C.K. Prahalad and Stuart Hart (Prahalad \& Hart, 2002), presented in their working paper a revolutionary concept of doing business in the world's poor markets known as the Bottom of Pyramid (BOP). Since then, this working paper has been an important reference to a series of academic and business articles all over the world, some them writing in a critical way (Jenkins, 2005; Karnani, 2007; Crabtree, 2007). These authors made the observation that about 4 billion people remain excluded from the system of the global economy. According to (Engel, 2011) "The world is experiencing a shift of power from the traditional industrialized countries to the so-called developing countries, already home to $80 \%$ of the world's population and with a combined GDP that surpasses that of the rich countries". It is also estimated that by the year 2050, more than 3 billion additional people will be living in what is now described as the developing world. Even though, in recent decades, a substantial progress has been made, inequity and poverty still remain a serious challenge for the development of a sustainable global stability. Poverty has many dimensions: about a third of the world's population lives on less than US $\$ 2$ a day and many suffer from malnutrition, lack of access to health services, sanitation, electricity, safe drinking water, shelter or transportation (Engel, 2011). In a report of the World Economic Forum (WEF, 2009) 1 prepared in collaboration with Boston Consulting Group, the situation of the BOP market is as shown in Figure 1. In this figure different segments of the BOP market are shown, based on income.

${ }^{1}$ The World Economic Forum is a Swiss nonprofit foundation. It is an independent international organization committed to improving the state of the world by engaging business, political, academic and other leaders of society to shape global, regional and industry agendas. 
Figure 1. Segments of BOP market on the basis of income

\section{The Base of the Pyramid can be divided into three segments on the basis of income}
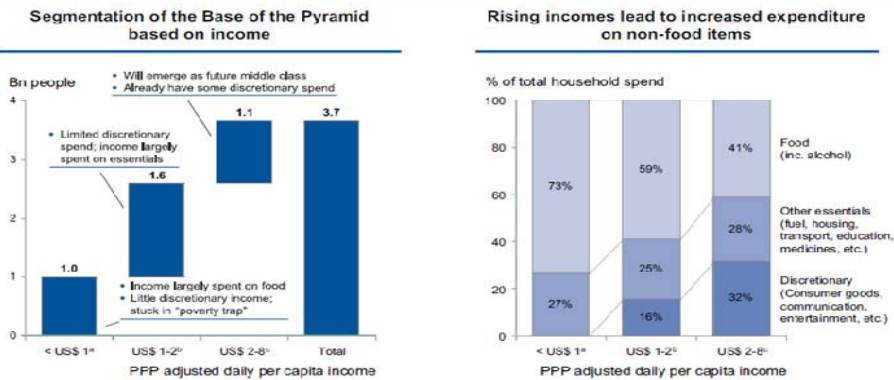

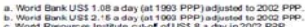

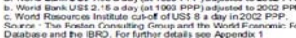

Source: "The Next Billions:Unleashing Business Potential in Untapped Markets" (The Boston Consulting Group and the World Economic Forum, 2009)

According to this organization: "Base of the pyramid" (BOP) is a collective reference to 3.7 billion people populating the lowest income strata in the world. The income threshold for this group is US\$ 3,000 per person per year (in 2002 PPP\$), or roughly US\$ 8 per person per day. Within this group are the "next billions" - a large group of consumers, producers and entrepreneurs who can be profitably engaged or served by business, albeit with new and innovative approaches. Within this report, the term "next billions" refers to the members of the BOP whom business has the opportunity to engage in the near term". If the usual development path is followed, meeting the basic needs of a growing and increasingly urbanized population will exponentially increase the demand for energy and natural resources, thereby further exacerbating the pressure on the world's ecosystems. This means that business as usual is not an option (Engel, 2011). It is also important for all the stakeholders involved in the BOP market to know where this market is mostly concentrated and where are the people of the BOP market living all over the world? The answer of this question could be shown in Figure 2 (WEF, 2009). As it can be seen in this figure, people living at the BOP can be found all over the world, yet they are particularly concentrated in a few areas. India and China alone account for $60 \%$. Asia, Africa and Latin America together account for $94 \%$ of the total BOP population. Africa has the highest share of the poorest segment - only $65 \%$ of Africa's BOP population is above the World Bank's US\$ 1 a day poverty line, compared with more than $86 \%$ in Latin America. The majority of the BOP live in rural areas (68\% globally), which adds to the complexity and costs of reaching them (WEF and Boston Consulting Group, 2009).

Figure 2. World concentration of people living in BOP markets

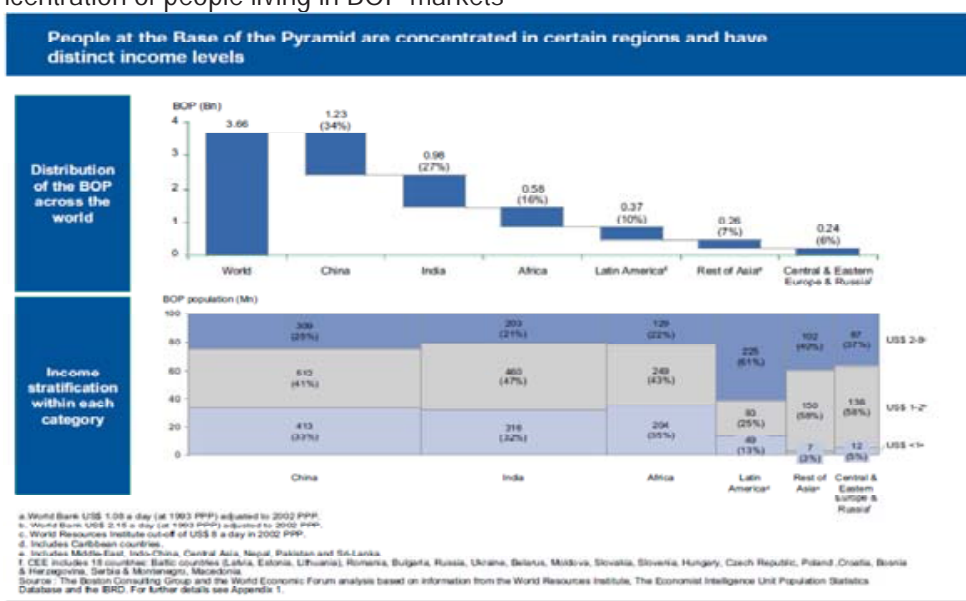

Source: "The Next Billions:Unleashing Business Potential in Untapped Markets" (The Boston Consulting Group and the World Economic Forum, 2009) 
The BOP concept encourages corporations to take into consideration this segment of the population, and consider this market as an opportunity to explore the untapped potential it presents. In this context, the BOP market represents a multibillion-dollar marketplace, which still remains unexploited from multinational or local companies. Maturing markets, floundering business models and insecurities about the characteristics of future customers, could be some of the reasons why corporations should pay attention to the BOP market. The market opportunity here is not just the wealthy few in the developing world, but the vast number of aspiring poor who are joining the market economy for the first time. ${ }^{2}$ Multinational companies must recognize that the bottom of the pyramid poses a fundamentally new question: How to combine low cost, good quality, sustainability, and profitability at the same time? ${ }^{3}$ This topic has been the core of several conferences and a growing number of authors, researchers and organizations are using the term BOP in their writings (Hart, 2005; Hart \& Christensen, 2002; London \& Hart, 2004; Prahalad, 2004; Rangan, Quelch, Herrero, \& Barton, 2007). Even more important regarding this issue, is the fact that interest and support of BOP ventures is increasingly occurring in the real life businesses. These ideas are crossing sectors, as organizations in the private, nonprofit, and development communities are interested in applying BOP ideas to their new initiatives (Gardetti, 2007). Interestingly, while much debate and most of the writings on this perspective have centered around who is in the BOP (Hammond, Kramer, Katz, Tran, \& Walker, 2007) and how BOP ventures need fundamentally new market entry strategies (Hart, 2005; Hart \& London, 2005), a deep exploration of the poverty alleviation implications has lagged (London, 2007b)4. Many authors attach BOP strategies to poverty alleviation policies, so what has not yet been fully articulated is how this perspective differs from other market-based poverty alleviation approaches, and thus, how its poverty alleviation outcomes may be different (London, 2007).

In this context, organizations and researchers have elaborated a series of strategies for BOP approaches to be successful where the key word is innovation. This market segment presents different characteristics from those of traditional markets. Often, low quality products at a lower price are one of the ways in which a company can access this market, but this could not be e sustainable and reliable strategy. The transformation of the bottom of the pyramid and the creation of a new and emerging market requires a total transformation of managerial practices in established MNCs. The traditional 4 P's of the marketing, product, price, promotion and placement needs to be re-engineered exclusively for the bottom of the pyramid (Sabeeha 2011). Ideas and suggestions on how and which organizations might engage with the BOP market, have been the core subjects of different researchers as well as activities of NGO-s and corporates (London, 2007; Seelos\&Mair, 2007).

Muhummad Yunus, Nobel prize-winner and founder of microcredit Grameen Bank in Bangladesh, expresses in his books the belief that any progress by the BOP will only come through an equal partnership with companies, who while prepared to be involved commercially, would be satisfied with less than profit maximization. ${ }^{5}$ In one of their articles (Wille and Barham, 2009) using a pilot study, try to give some comprehensive samples of business activity at the Bottom of the Pyramid in the developing world. They give some models of business involvement in the BOP. According to Academics at Cornell University ${ }^{6}$, three working models could be used for engaging with the BOP (Wille and Barham, 2009):

- The provider model, which works on normal business principles, where the company determines what products and services to sell, consistent with their core competencies

- The empowerment model, where the company listens to the potential customers and adopts its products to the needs as seen by the BOP customers.

- The partnership model, in which the company enters into a joint venture with a BOP community to co-create a business to be decided upon by both parties and to be run jointly until the community members are able to take full control.

\footnotetext{
${ }^{2}$ C. K. Prahalad, Stuart L. Hart Strategies for the Bottom of the Pyramid:Creating Sustainable Development www.nd.edu/ $\mathrm{kmatta}$ Imgt648/strategies

${ }^{3}$ C. K. Prahalad, Stuart L. Hart Strategies for the Bottom of the Pyramid:Creating Sustainable Development www.nd.edu/ $\sim$ kmatta /mgt648/strategies

${ }^{4}$ London, T. (2007) A Base-of-the-Pyramid Perspective on Poverty Alleviation

${ }^{5}$ Yunus, M. (2003) Banker to the Poor, Aurum Press; and Yunus, M. (2007) Creating a World Without Poverty: Social Business and the Future of Capitalism, Public Affairs Books.

${ }^{6}$ Simanis, E., Duke, D. and Hart, S. (2008) The Base of the Pyramid Protocol: Beyond 5 Basic Needs Strategies, Innovations, Winter.
} 


\section{Implementation of BoP Strategies in Practice}

Several companies and organizations have already approached the BOP market using different strategies based on their profile and market needs. Terms used on the projects of these institutions like "inclusive business strategies" or "base of pyramid" and "social entrepreneurship" etc., all have in their roots the BOP market concept. One of these initiatives (for e.g.) is the UNDP's "Growing Inclusive Markets" (GIM) project which is "a UNDP-led global multi-stakeholder research and advocacy initiative that seeks to understand, enable and inspire the development of more inclusive business models around the globe that will help to create new opportunities and better lives for many of the world's poor". Companies like Starbucks, Unilever, Coca Cola, Wal-Mart and many others have already engaged in business strategies to BOP market. The websites and annual reports of fortune global-500 companies show that nearly all of them are to a certain extent serving the poorest of our world, the so-called "base of the pyramid" (Grootvelt, 2009). Other organizations, like the World Business Council for Sustainable Development (WBCSD) ${ }^{7}$, Netherlands Development Organization (SNV) and International Finance Corporation IFC) ${ }^{8}$, have already developed and implemented different projects and strategies for companies to successfully operate in the BOP market. In order to be successful, these strategies must create a win-win situation between companies, suppliers, and community as shown in Table 1. As it can be seen from this table, a successful path for a company in the BOP market can be achieved in collaboration with suppliers, partners, distributors and consumers. Key words for the strategy of the company to take into consideration are: product innovation, fair trade markets, access to quality products, affordable prices and increased productivity. On the one side, inclusive business models aim to provide innovative solutions to supply affordable products and services to meet basic needs of the poor for water, food, sanitation, housing and healthcare. On the other side, they are also about creating income and employment opportunities for low-income communities-either directly or through companies' value chains as suppliers, distributors, retailers and service providers (Engel, 2011).

Table 1. Benefits of inclusive business

\begin{tabular}{|c|c|}
\hline \multicolumn{2}{|l|}{ With Partners, Suppliers And Distributors } \\
\hline For The Company & For The Low Income Community \\
\hline Secure supply of raw materials. & Fair prices and conditions \\
\hline Traceability and quality control of raw-materials. & Assured sales. \\
\hline Lower transaction costs. & Employment creation and expansion \\
\hline Shared risks. & Training and technical assistance \\
\hline Access to knowledge and local networks. & Technology and knowledge transfer \\
\hline Better relations with government & Access to financing \\
\hline $\begin{array}{l}\text { Strategic positioning in new fair trade } \\
\text { markets. }\end{array}$ & $\begin{array}{l}\text { Participation in a business and investment } \\
\text { environment }\end{array}$ \\
\hline \multicolumn{2}{|l|}{ With Consumers } \\
\hline For The Company & For The Low Income Community \\
\hline Access to new markets & Greater access to quality products and services \\
\hline Increased income. & Lower and more affordable prices \\
\hline Transfer of product innovations to existing markets. & Better quality of life \\
\hline $\begin{array}{l}\text { Increased brand value and positioning in order to } \\
\text { capture new markets }\end{array}$ & Increased productivity \\
\hline
\end{tabular}

Source: SNV and WBCSD, 2008: 13, (Jenkins, Ishikawa, Geaneotes, Baptista and Masuoka, 2011: 2 - 3.) in a report for IFC, represent these business models included in the IFC portfolio as shown in Table 2.

\footnotetext{
${ }^{7}$ The World Business Council for Sustainable Development (WBCSD) is a CEO-led, global coalition of some 200 companies advocating for progress on sustainable development. Its mission is to be a catalyst for innovation and sustainable growth in a world where resources are increasingly limited.

${ }^{8}$ IFC is a member of the World Bank Group and invests in the private sector. In 2011, IFC invested $\$ 12.2$ billion in 518 projects, of which $\$ 4.9$ billion went to the poorest countries eligible to borrow from the World Bank's International Development Association. We also mobilized an additional $\$ 6.5$ billion to support the private sector in developing countries.
} 
Table 2. Business models in the IFC's portfolio

\begin{tabular}{|c|c|}
\hline Business Model & Explanation \\
\hline $\begin{array}{l}\text { Micro Distribution } \\
\text { and Retail }\end{array}$ & $\begin{array}{l}\text { Reaches base of the pyramid (BOP) end consumers who tend to make small, frequent purchases } \\
\text { close to home by leveraging and effectively serving existing retail outlets in the neighborhoods } \\
\text { where those consumers live. Such outlets are often small, with little space for excess inventory, } \\
\text { and run by staff with little business training, scarce working capital, and no access to finance. They } \\
\text { need small, frequent deliveries and the ability to buy on credit. They may need custom } \\
\text { assortments and/or small-sized products (e.g., airtime cards in small denominations) or pay-per-- } \\
\text { use services (e.g., minutes of shared mobile phone use) that match BOP consumers' limited, } \\
\text { sporadic cash-flows. Many companies using the Micro Distribution and Retail model also provide } \\
\text { business skills training and other forms of support to help such retail outlets increase sales, } \\
\text { recognizing the link between the outlet's business success and the company's own. }\end{array}$ \\
\hline $\begin{array}{l}\text { Experience- } \\
\text { based Customer } \\
\text { Credit }\end{array}$ & $\begin{array}{l}\text { Generates additional revenue in the form of interest income through lending to customers the } \\
\text { company knows are credit-worthy through experience doing business with them in the past- } \\
\text { rather than formal credit histories. The model is generally employed by companies outside the } \\
\text { financial sector, though some may have credit arms or subsidiaries. Some companies focus on } \\
\text { their direct customers. One company lends to its customers' customers as well, based on the } \\
\text { experience its customers have had with those people in the past (and leveraging their existing } \\
\text { relationships to help incentivize repayment).The model is predicated upon limited access to other } \\
\text { sources of credit at similar rates or for similar purposes. }\end{array}$ \\
\hline $\begin{array}{l}\text { Last-Mile Grid } \\
\text { Utilities }\end{array}$ & $\begin{array}{l}\text { Extends grid coverage to more distant and often lower-income neighborhoods through a } \\
\text { combination of financing, technology, and customer service innovations that help cover capital } \\
\text { expenditures, minimize technical and commercial losses, and ensure customers pay on time. The } \\
\text { model is based on a clear value proposition to the consumer: greater quality, reliability, } \\
\text { convenience, and in many cases, lower cost compared to previously available, often informal utility } \\
\text { options }\end{array}$ \\
\hline $\begin{array}{l}\text { Smallholder } \\
\text { Procurement }\end{array}$ & $\begin{array}{l}\text { Turning geographically dispersed smallholder farmers into reliable sources of quality supply } \\
\text { through efficient aggregation methods and customized packages of support services that build } \\
\text { capacity and loyalty. Common support services include agricultural extension, business } \\
\text { development, access to agricultural inputs, and credit. Sometimes, buyers choose to focus on } \\
\text { higher value crops capable of earning a premium in the marketplace to help cover the cost of such } \\
\text { support }\end{array}$ \\
\hline $\begin{array}{l}\text { Value-for-Money } \\
\text { Degrees }\end{array}$ & $\begin{array}{l}\text { Makes university education accessible to all through a combination of innovations that increase } \\
\text { affordability and value for lower-income students. To increase affordability, these universities use } \\
\text { standardized curricula that can be taught by part-time instructors, accessible physical and virtual } \\
\text { campuses that reduce students' transportation costs, modular programming that matches cash } \\
\text { flows and access to student loan financing. To create value, they offer course content and career } \\
\text { services tailored to the job market. }\end{array}$ \\
\hline $\begin{array}{l}\text { Value-for-Money } \\
\text { Housing }\end{array}$ & $\begin{array}{l}\text { Makes home ownership possible for lower-income buyers through a combination of high value for } \\
\text { money and facilitated access to mortgage financing. A home is the biggest investment most } \\
\text { people ever make and they have to be convinced it is worth the commitment, which can feel risky. } \\
\text { Value-for-money housing balances aspiration (with a focus on quality, special features, and the } \\
\text { community environment) and affordability (with home sizes and layouts in different price ranges, } \\
\text { and features that reduce the ongoing cost of ownership). Because the model hinges upon access } \\
\text { to financing, it often involves helping homebuyers-often the first in their families-navigate the } \\
\text { mortgage application process. }\end{array}$ \\
\hline $\begin{array}{l}\text { E-Transaction } \\
\text { Platforms }\end{array}$ & $\begin{array}{l}\text { Many low-income people lack access to financial services as a result of the high transaction costs } \\
\text { and complex logistics involved in reaching them. Technology companies are beginning to address } \\
\text { these challenges through electronic transaction platforms, creating opportunities to serve low- } \\
\text { income customers and bringing them benefits spanning convenience, efficiency, security, market } \\
\text { access, and integration into the formal financial system. IFC is investing in a diverse set of } \\
\text { technology companies that are helping o create the complex infrastructure for a cashless society } \\
\text { to function. These companies have different business models. However, at a fundamental level, } \\
\text { they display some interesting similarities-like leveraging existing retail outlets and networks, } \\
\text { building outlets' business and technology skills, raising consumer awareness and helping them } \\
\text { understand the value proposition behind cashless transactions }\end{array}$ \\
\hline
\end{tabular}

Source: Jenkins, Ishikawa, Geaneotes, Baptista and Masuoka, 2011: 2 - 3. 
Other researches (WBCSD for e.g.) have identified three essential factors for the companies that wish to implement inclusive business projects ${ }^{9}$ : First, a company should focus on its core competencies and strengths - which could be vital in ensuring consistency in a company's portfolio. Second, it should partner with government agencies, civil society groups and development organizations with on-the ground expertise. Lastly, it should tap into local networks to gain insights into regional markets of developing nations. It should also be noted that the implementation of inclusive business projects is by no means restricted to multinational companies. On the contrary, given the market structure, entrepreneurs in developing countries have always had to adapt their business models to cater for low-income consumers.

\section{Poverty and Social Business Opportunnities in Albania}

According to IFAD ${ }^{10}$, Albania is one of the poorest countries in Europe. The effects of the transition from a centralized economy in a rigid communist state to a free market economy in a democratic republic have weighed heavily on Albania's people, and particularly on its poor people. Despite the economy's robust growth in recent years, almost one quarter of the population lives below the poverty level of US\$ 2 a day. The poorest of the poor, who comprise about 5 per cent of the population, struggle to put adequate food on the table each day.

The income gap in the country is relatively small. Because of low incomes and a low employment rate most people's average incomes hover close to the poverty line. This makes many of them vulnerable to the effects of downturns in the economy. It also means that well-directed pro-poor policies can potentially benefit large numbers of people.

As in many countries, the incidence of poverty is highest in rural areas, where an estimated 57 per cent of Albania's people live and where most of them depend on agriculture for their livelihood. Poverty is 66 per cent higher in rural areas than in Tirana, the capital, and it is 50 per cent higher in rural areas than in other urban centers. The agricultural labour force is heavily underemployed, and about half of all farm laborers work only part time. For rural Albanians, non-farm employment and the opportunities it offers are a potential means of rising out of poverty. Rural, northern and mountainous areas are the poorest areas in the country. The incidence of poverty is highest in the northeastern districts of Kukes and Dibra, where almost half of the population is poor and 80 per cent of families' income comes from social protection schemes, economic assistance and disability payments.

In this context, a few companies mainly operating with this strata of the population have emerged during the last years in Albania. These companies operate mostly in food processing, recycling, and micro financing industries. Of course this is a new trend of business, including the poor in companies' everyday activities. One of the most representative cases of such a company is that of Edipack Sh.A. located in the city of Durres. The company receives its inputs from small individual suppliers as well as from two waste management companies. With the aim of including poor and vulnerable people in its supply chain and generating income opportunities for them, Edipack partners with three NGOs, which coordinate paper collection from about 120 individual collectors from vulnerable groups. By employing and providing on-the-job training to 75 low-skilled employees in the production process, Edipack further contributes to social inclusion. Edipack produces a large variety of goods, including sheets of corrugated paper, sophisticated packaging materials such as cosmetics paper boxes and packaging for agricultural products or beverages. The company currently has over 370 clients and sells its products to a variety of businesses, the majority of which are small and medium sized Albanian enterprises ${ }^{11}$.

\section{Conclusions}

The interest on the BOP concept is increasing among researchers, academics, corporate and a series of governmental and non-governmental organizations. Even though different theoretical opinions exist on the fact that this could be a successful business strategy for a company or not, a large number of companies and organizations that have already successfully approached the BOP market can be identified. It is not difficult to identify the areas of the world where the BOP market is extended, but it is difficult to prescribe standard strategies of success as they vary depending on the company, the BOP market segment and its needs, etc. In this context, further research is needed to identify the

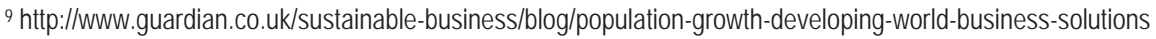

${ }^{10} \mathrm{http}: / /$ www.ruralpovertyportal.org/country/home/tags/albania

${ }^{11}$ Edipack: a Paper Recycling Pioneer, Growing Inclusive Markets, UNDP, 2010
} 
characteristics of a BOP market and the right strategy for different regions, countries and even local markets and businesses.

\section{References}

Crabtree, A. (2007), Evaluating the "bottom of the pyramid" from a fundamental capabilities perspective, CBDS Working Paper Series, Working Paper Nr. 1

Engel, M. (2011), Business as usual is not an option in developing countries, The Guardian, http://www.guardian.co.uk/sustainablebusiness/blog/population-growth-developing-world- business-solutions

Gardetti, M. A.( 2007), A base-of-the-pyramid approach in Argentina: Preliminary findings for a BOP Lab. Greener Management International, 51: 65-77

Grootvelt, P. (2009), Strategies for the Base of the Pyramid. Becoming trusted at the Base of the Pyramid, Master Thesis, Tilburg University

Hammond, A. L., Kramer, W. J., Katz, R. S., Tran, J. T., \& Walker, C. (2007), The Next Four Billion: Market Size and Business Strategy at the Base of the Pyramid. Washington, DC: World Resources Institute and International Finance Corporation

Hart, S. L. (2005), Capitalism at the Crossroads: The Unlimited Business Opportunities in Serving the World's Most Difficult Problems. Upper Saddle River, NJ: Wharton School Publishing

Hart, S. L., \& Christensen, C. M. (2002), The great leap: Driving innovation from the base of the pyramid. Sloan Management Review, 44(1): 51-56.

Jenkins, R (2005), Globalization,Corporate Social Responsibility and poverty. International Affairs 81(3) pp 525-540

Jenkins, B; Ishikawa, E; Geaneotes, A; Baptista, P; and Masuoka, T (2011). Accelerating Inclusive Business Opportunities: Business Models that Make a Difference. Washington, DC: IFC.

Karnani, A. (2007), The Mirage of Marketing to the Bottom of the Pyramid. How the private sector can help alleviate poverty. California Management Review, 49 (4), 90-111

London, T. (2007), A Base-of-the-Pyramid Perspective on Poverty Alleviation, Working Paper, William Davidson Institute/Stephen M. Ross School of Business

London, T., \& Hart, S. L. (2004), Reinventing strategies for emerging markets: Beyond the transnational model. Journal of International Business Studies, 35(5): 350-370

Prahalad, C. K. (2004), The Fortune at the Bottom of the Pyramid: Eradicating Poverty Through Profits. Upper Saddle River, NJ: Wharton School Publishing

Prahalad, C.K. and Hart, S.L. (2002), The Fortune at the Bottom of the Pyramid, strategy+business, issue 26, first quarter

Rangan, V. K., Quelch, J. A., Herrero, G., \& Barton, B.( 2007), Business Solutions for the Global Poor: Creating Social and Economic Value. San Francisco: Jossey-Bass.

Sabeeha, F. (2011), 4 P's for the Bottom of Pyramid, Conference on Inclusive \& Sustainable Growth, Institute of Management Technology

Seelos, C., Mair, J. (2007), Profitable Business Models and Market Creation in the Context of Deep Poverty: A Strategic View, Perspectives, Academy of Management

Simanis, E., Hart, S., Enk, G., Duke, D., Gordon, M., \& Lippert, A. (2004), Base of the Pyramid Protocol. Ithaca, NY: Cornell University, Working Paper.

SNV and WBCSD, (2008), Inclusive Business, Profitable Business for Successful Development, http://wwww.inclusivebusiness.org /2008/03/new-alliance-br.html

Wille, E., Barham, K. (2009), A role for Business at the Bottom of the Pyramid, The Ashridge Journal, Spring 2009. 